\title{
Senior Secondary School Science Teachers in Delta and Edo States Conceptualization about the Nature of Science
}

\author{
Patrick Osawaru Ajaja \\ E-mail: osawaruajaja@yahoo.com
}

$\begin{array}{lr}\text { Received: September 9, } 2011 \quad \text { Accepted: September 26, } 2011 \quad \text { Online Published: April 23, } 2012 \\ \text { doi:10.5539/ies.v5n3p67 } & \text { URL: http://dx.doi.org/10.5539/ies.v5n3p67 }\end{array}$

\begin{abstract}
The major purpose of this study was to find out the conceptions of science teachers about the nature of science. To guide this study, four research questions were asked and four hypotheses tested. The design of the study was descriptive survey and instrument used for data collection was a 22 item questionnaire. The sample of the study consisted of 400 science teachers drawn from senior secondary schools in Edo and Delta states. The data collected were analyzed with simple percentages and Chi square statistics. The major findings of the study included: (i) higher percentage of science teachers selected options which agreed with traditionalist's view on NOS; (ii) of the 22 items, in17 of them a higher proportion of science teachers conceived science from the traditionalist's view as against 5 for the constructivist view; (iii) a significant difference between the proportions of science teachers who opted for either traditionalist's or constructivist's view in all items except item 11; (iv) non-significant difference between the proportion of male and female science teachers on conception of science from the traditionalist's view; (v) significant differences in the proportions of male and female science teachers only in items 6,8,9 and 12 on the conception of science from the constructivist's view; (vi) non-significant difference in the proportions of urban and rural science teachers on conception of science from the traditionalist's view while significant differences were found between them only in items 2,6,10,12 and 17 on constructivist's view; and (vii) non-significant difference in the proportion of NCE, B.Sc (Ed) and B.Sc holders on conceptions of science from the traditionalist's view in all items except in item 17 while significant differences were found between them only in items 4,9,17 and 20 on constructivist's view. It is concluded that this trend in the conception of NOS can only be reversed through a deliberate science teacher preparatory curricula reform to include elements of constructivism.
\end{abstract}

Keywords: Conceptualization, Science, Teacher, Nature, Proportion

\section{Introduction}

\subsection{Background of Study}

Reforms in science education emphasize teaching science for all with the sole and ultimate purpose of developing scientific literacy. In this light, science teachers must go beyond simply teaching science as a body of knowledge. Today's teachers are challenged to engage students in a broader view of science, one that addresses the development of scientific knowledge and the way nature of the knowledge itself is (National Research Council, 1996). This implies that science teachers are encouraged and mandated to teach about the nature of science.

The role of science education in the socio-economic development of the societies and nations hardly needs any augments or discussions (Iqbal, Azam, \& Rana, 2009). They noted that it is because of this realization that science education has found a secured place in school curricula in almost every country around the world, particularly since the last two decades. Iqbal et al (2009), still maintained that the modern science curricula in various countries of the world, do not solely focus on developing the understanding of science concepts in students. It encompasses a wide variety of goals. Ajaja (2009a) for example, identified four major objectives for teaching science in Nigeria. These include:

(i) provision of basic training skills in scientific investigation;

(ii) provision of basic scientific literacy for everyday living;

(iii) provision of the basic skills and attitudes necessary for technological take-off and development; and

(iv) to stimulate and enhance the creativity of the child.

However, recent science curricula reforms in developed countries, have put added emphases on developing students' 
understanding about the nature of science (American Association for the Advancement of Science (AAS), 1990; and National Research Council (NRC), 1996). This aspect of science education has not taking roots in most developing countries like Nigeria.

This study was inspired by the findings on current studies about teachers' conceptions of nature of science. Some of the researchers who carried out these studies include; Iqbal et al (2009), Shah (2009), kucuk (2008), Halai \& Mcnicholl (2004) and Thye \& Kwen (2003). The findings of these researchers indicated that most of the science teachers (pre-service and in -service) possessed ill-informed views about the nature of science. A link between this findings and observed practices in the science classes in Nigeria, where the major method of instruction is lecture, laboratories are ill-equipped and laboratories exercises are hardly carried out by teachers and students, tends to suggest that the protracted poor performances of students in science subjects (Chemistry, Biology and Physics) as shown by WAEC (2006, 2007, 2008, 2009 \& 2010) may be traced to the wrong conceptions of what today's nature of science is. This may have influenced the teacher's choice of instructional methods and other practices in science classrooms. This study, intends to find out if the conceptions of science teachers in Nigeria about the nature of science are different from those held in other countries.

The nature of science is a multifaceted concept which cannot be defined with a simple definition. For the reason that it is a fusion of history , sociology and philosophy of science, it has being variously defined by different people at different times as science epistemology, the characteristics of scientific knowledge and science as a way of knowing (Bell, 2008). Abd-EL-Khalick, Bell and Lederman (1998, P 418) stated "typically the nature of science has been used to refer to the epistemology of science, science as a way of knowing, or the values and beliefs inherent to the development of scientific knowledge "Lederman (1998), sees the nature of science to refer to the values and assumptions inherent to scientific knowledge. Still stressing the lack of consensus among researchers on the meaning of nature of science, Abd-EL-khalick and Lederman, (2008) stated that the situation was so because the nature of science is multifaceted, dynamic and complex concept. Lederman (1998), and Lederman, Schwartz, Abd-EL-Khaliick \& Bell (2002) characterized nature of science as being empirical, inferential, creative, theory laden as well as socially and culturally influenced.

Ajaja (2009a) sees the nature of science as a complex aggregate involving the process by which scientists gather and analyze scientific ideas; the products of science, the ethics and assumptions of science and the act of scientific investigations. The methods of science include the way by which information is gathered, analyzed, synthesized and disseminated. The products of science are; concepts, laws and theories by which regularities in natural phenomena are described, explained, predicted upon which the meaning of scientific contents depends. while ethics and assumptions are the written and unwritten ethical and conventional systems guiding the scientific community in its methodological inquiry.

Literature on nature of science indicates that teaching nature of science to students has long been a goal of science educators (Kucuk, 2008; Akerson \& Volrich, 2006; Kang; Cobern \& Loving, 2002). Early attempts to improve the knowledge of nature of science, particularly students conceptions of nature of science, primarily focused on the development of curricula materials (Kucuk, 2008). The products of these developments were the development of physical science and Biological science curricula. One of the major issues which emerged from the curricula innovations of the period was the realization that teachers play an absolutely critical role in nature of science instruction (Kucuk, 2008). This resulted in the re-direction of research efforts towards assessing pre-service and in-service teacher's understanding of the nature of science. A study tailored toward this direction was the work of Kucuk (2008) who found that training on nature of science had positive changes in pre-service teacher's view about the nature of science by using conceptual change and cooperative learning techniques; Also Lin and Chen (2002) were able to demonstrate a modest change in chemistry teachers' understanding of the nature of science through teaching history of science course.

Current research efforts on the nature of science are concentrated on assessing science teachers conceptions of nature of science and prominent among these are the studies by Iqbal et al (2009), Shah (2009), Kucuk (2008). Halai and MCNicholl (2004) and Thye and Kwen (2003). The findings of these researchers indicated that a greater proportion of science teachers hold an inadequate understanding of nature science. This implies that science teaching and practices in most schools in the developing countries do not follow the recommended standard of use of guided inquiry/discovery and process skills.

Lederman (2006) after the appraisal of 50 years of research on nature of science based on science classroom interaction summarized his findings as follows:

(i) K-12 students do not typically possess "adequate " conceptions of nature of science

(ii) K-12 teachers do not typically possess "adequate " conceptions of nature of science 
(iii) Conceptions of nature of science are best learned through explicit, reflective instruction as opposed to implicitly, through experiences with simply "doing" science.

(iv) Teacher's conceptions of nature of science are not automatically and necessarily translated into classroom practice.

(v) Teachers do not regard nature of science as an instructional outcome of equal status with that of "traditional "subject matter outcomes.

Literature on nature of science also indicates that teachers' conceptions of nature of science are influenced by language, beliefs, culture, textbooks used, and conviction on the right instructional approach for teaching. Iqbal et al (2009) stated that student's conception about the nature of science is relatively fixed. They noted that science teachers' beliefs about the best way of teaching science are previously conceived and developed from their experiences as students. The kind of beliefs held by students influence their attitude and disposition in science classes. For example, Lin, Chiu and Chau (2002) found that students having post-positivist-oriented views about science tended to recall more information and, show more flexibility, and demonstrate better mental cognitive ability than students with empiricist aligned epistemological beliefs.

Teachers' conceptions of nature of science are again influenced by the kinds of textbooks they use for instruction. Gallangher (1991) found that secondary schools science teachers respond to textbooks in a way that contribute to transmission mode of science teaching. Iqbal et al (2009) stated that various studies revealed that in any classroom, the science taught and the way it is taught depends primarily on what the teacher believes, knows and does.

Science teacher's conceptions about the nature of science influence their choices of instructional approaches; whether traditional or contemporary. The traditional approach starts from predetermined body of knowledge while the contemporary or constructivist starts from the learner rather than any predetermined body of knowledge. In the traditional approach, it is the duty of science teachers to pass the pre-determined body of knowledge to the students. The constructivists maintain that individuals create and construct their own new understandings of knowledge through their new understandings of knowledge through the interaction of what they already know and believe and the ideas, events, and activities with which they came in contact with (Richardson, 1997). Today's nature of science emphasizes that knowledge should be constructed and created by the learner rather than knowledge being dispensed to him by the teacher who is assumed to be a reservoir of knowledge.

This study which essentially drew its inspiration from current research efforts on teachers' conceptions of nature of science worldwide and the intention of contributing towards re-positioning the teaching and learning of science in Nigeria has the main purpose of finding out the conceptualization of science teachers about the nature of science in Delta and Edo states. Science is taught at senior secondary level in Nigeria as Biology, Chemistry and Physics. The specific areas of emphasizes in this study are: determination of conceptions of nature of science by science teachers, science teachers of different sexes ,science teachers in different localities, and science teachers with varying qualifications in Delta and Edo states of Nigeria.

\subsection{Statement of the Problem}

This study which was motivated by research findings in other developing countries like our own on teachers conceptions of the nature of science was in part driven by the fact that very little is known about teachers conceptions of the nature of science in Nigeria and the observed science classroom practices not being in line with recommended standards. The recommended standards for science teaching are that science instruction should centre on guided inquiry/discovery while all science students' classroom activities should be process skills based. These are however, not the practices in our science classrooms where the major approach to instruction is lecture method. It is felt that the teachers' conceptions about the nature of science may have influenced their choice of instructional methods.

The statement of problem therefore is, will the evaluation of science teachers' notions about science and their classroom practices generate data that can be used to determine their conceptions of the nature of science?

\subsection{Research Questions}

To guide this study, the following research questions were raised and answered.

1) What is the conception of science teachers on the nature of science?

2) What are the conceptions of male and female science teachers on the nature of science?

3) What are the conceptions of science teachers in the urban and rural areas on the nature of science?

4) What are the conceptions of science teachers with varying qualifications on nature of science? 


\section{Hypotheses}

$\mathrm{Ho}_{1}$; The proportion of science teachers who conceive science from the traditionalist's point of view is not significantly different from those who conceive it from the constructivist's view.

$\mathrm{Ho}_{2}$; There is no significant difference in the conceptions of male and female teachers on the nature of science.

$\mathrm{Ho}_{3}$; There is no significant difference in the conceptions of urban and rural science teachers on the nature of science.

$\mathrm{Ho}_{4}$; There is no significant difference in the conceptions of science teachers with NCE, B.Sc. (Ed), and B.Sc certificates on the nature of science.

\section{Methodology}

\subsection{Design of Study}

The design of the study was a descriptive survey. A questionnaire was used to collect data from a sample of the population about their conceptions about the nature of science. Generalizations were made about the population from the data generated from the representative sample. The design was most appropriate for the study since questionnaire was used for data collection. As a rule in research, any study where questionnaire is used for data collection, the design for such a study is described as survey. This agrees with the recommendations of Wiseman (1999) and Johnson \& Christensen (2000).

\subsection{Sample and Sampling Technique}

The sample of the study consisted of 400 science teachers drawn from 200 senior secondary schools in Edo and 200 senior secondary schools in Delta state. Science is taught in senior secondary schools in Nigeria as Biology, Chemistry and Physics. Of the 200 science teachers selected in Edo state, 100 were from Benin City the state capital while the remaining 100 subjects were drawn from Igueben, Esako west and Egor local government areas. In Delta state, of the 200 subjects, 100 were drawn from Asaba the state capital while the remaining 100 science teachers were selected from Ika North East, Ethiope East and Sapele local government areas. These schools from where the science teachers were selected are $50 \%$ public and $50 \%$ private in the two states.

The sampling technique employed in the selection of subjects was purposive simple random sampling using balloting: to reflect sex, school location and kinds of certificates possessed by science teachers. All the science teachers selected for the study were all trained in tertiary institutions in Nigeria. This brought all the science teachers to have had similar experiences. All science teachers trained abroad were excluded from the study. Only one science teacher was selected from each of the selected schools.

\subsection{Instrument}

The instrument used for this study was a questionnaire called Teachers Conception of Nature of Science Questionnaire (TCNSQ). The instrument was adapted from the work of Iqbal et al (2009) but was originally constructed by Haider (1999). The instrument consisted of two sections A \&B; Section A dealt with demographic information while section B consisted of five categories containing twenty two (22) items. All the items were close ended questions. Appendix 1 shows the instrument. Category 1 contains items that dealt with scientific theories; Category 2 contains items that dealt with the role of scientists; Category 3 contains items that dealt with scientific knowledge; Category 4 contains items that dealt with scientific methods; and Category 5 contains items that dealt with scientific laws. The questionnaire was structured in a bipolar form meaning that two statements were given for each item. Statement A depicted the traditionalist's views about a particular aspect of science while statement B depicted the constructivist's views of science. Attached to each statement were two boxes with options of "yes" and "Do not know" for respondents to tick based on their conceptions about nature of science. The respondents responded to either statements A or B and not both. This restriction was necessary to avoid a situation where a respondent chooses one type of response for statements $\mathrm{A}$ and $\mathrm{B}$. The instrument was re-validated because of its adaption to suit the study.

The validity of the instrument was determined by a panel of five Judges which consisted of three specialist science educators (Biology, Chemistry and Physics educators) and two experts in measurement and evaluation. They all confirmed suitable face and content validities after scrutinizing the research questions and hypotheses. In fact, they affirmed that the instrument will be able to generate data to answer the research questions and test the stated hypotheses.

The reliability of the instrument was determined using Crombach Alpha. To achieve this, the TCNQ was administered on 20 teachers who were not part of the study. Their responses were coded and the data generated used to determine the reliability of the instrument using Crombach's alpha formulae. 
The calculated Alpha was 0.79 which indicated that the instrument was reliable. The reliability index of 0.79 showed that the instrument has measured the characteristics it was designed to measure. This agrees with the recommendations of Thorndike and Hagen (1997), Wiseman (1999), Johnson and Christensen (2000) and Borich (2004) that a high reliability value of 0.70 or higher shows that an instrument is reliable. This resulted in using the instrument for the study.

\subsection{Method of Data Collection}

The data collection was done by a team of thirteen, which consisted of the researcher and twelve research assistants. Six research assistant were allocated to each state. Of the six research assistants allocated to each state, three of them collected data in the state capital, while one research assistant collected in each of the three local government areas.

A week before the commencement of data collection the researcher together with the research assistants allocated to each state held a meeting in each state capital. In Benin, the state capital of Edo State, the meeting was held in the Teaching Service Board (TSB) premises. While in Asaba, the Delta State capital, the meeting was held in the Post Primary Board Premises (PPB). These venues were selected for the meeting because it afforded the researcher the opportunity to obtain comprehensive lists of schools in the states and their locations.

During the meetings the researcher together with the research assistants went through the questionnaire (TCNSQ). They were specifically told to give the questionnaires to only science teachers (Chemistry, Biology and Physics) in selected public and private schools. They were asked to collect the questionnaire from the respondents immediately after their responses. This was done to ensure $100 \%$ return rate and to reduce the incidence of seeking the opinion of others before responding. The research assistants were finally told that they have a maximum of one week within which to distribute the questionnaires.

Exactly one week after the distribution of the questionnaires, the researcher held another meeting with the research assistants in each of the state capitals. The Benin meeting was held on Monday of the week in the same venue (TSB) as stated earlier. While Asaba meeting was held on Tuesday at PPB. During the meetings, the researcher and the research assistants collated the science teachers responses to the items in the questionnaire in line with research questions raised for the study. The responses of the science teachers in the two states were merged and presented as single sets of scores to each item in the categories. The frequency of responses for each item in the categories was expressed in percentages. The data collected were summarized in tables as shown under results. The hypotheses were tested with Chi square statistic at 0.05 level of significance

\section{Results}

Shown in table 1, the conception of science teachers about the nature of science followed the traditional approach. Total percentage average for all the categories showed that $62.01 \%$ of science teachers saw science from the traditionalists' point of view, while $31.34 \%$ of them saw it from constructivists' outlook. Specifically, on Scientific Theories; while $51.4 \%$ of the science teachers conceived them from the traditionalists' point of view, $38.8 \%$ of them conceived them from the constructivists' perspective. On the Role of Scientists; $77.00 \%$ of science teachers followed the traditionalists' approach while $17.4 \%$ followed the constructivists' perspective. On Scientific Knowledge, 54.0\% of the science teachers chose the options which favoured the traditionalists' approach while $41.60 \%$ chose the options that agreed with the constructivists' approach. On Scientific Methods; $71 \%$ of science teachers chose options that agreed with the traditionalist's approach while $22.25 \%$ chose options that are in line with the constructivists' view. On Scientific Laws; $56.67 \%$ of science teachers agreed with the traditionalists' ideals about science while 36.67 of them agreed with the constructivists' ideas about science.

Table 2 shows that the proportions of science teachers who conceived science from the traditionalists' point of view were significantly different from those who conceived it from the Constructivists' views in all categories except in item 11 which showed no significant difference. With these findings, $\mathrm{H}_{\mathrm{O} 1}$ was rejected.

Table 3 shows that the conceptions of male and female science teachers about the nature of science followed a similar pattern. The total sample average for all the categories indicated that while $60.10 \%$ of male teachers chose options which are in line with the traditionalists' approach to science, $63.53 \%$ of female science teachers did the same. On the other hand, $34.45 \%$ of male teachers agreed with the constructivists' approach to science while $29.93 \%$ of female teachers towed the same line. In all the specific categories (Scientific Theories, Role of Scientist, Scientific Knowledge, Scientific Methods, and Scientific Laws) the percentages of male and female science teachers who chose options that are in line with the traditionalists' notion about the nature of science were greater than those who chose the options that agreed with the constructivists' idea about the nature of science.

Table 4 indicates that there is no significant difference in the proportions of male and female science teachers who agreed to the traditionalists' conceptions about the nature of science. Also shown in the table the proportion of males 
and females who agreed to constructivists' conceptions about the nature of science were not significantly different in all the items except in items 6, 8, 9 and 18 where significant differences were found. With this finding, $\mathrm{H}_{\mathrm{O} 2}$ was retained.

Shown in table 5, the conceptions of science teachers in both rural and urban areas did not vary. On total average for all categories, while $61.87 \%$ of science teachers in the urban schools conceive science from the traditionalists' outlook, $61.73 \%$ of them in the rural schools also saw the nature of science in that similar way. On the constructivists' approach, $31.70 \%$ and $31.61 \%$ of urban and rural science teachers respectively conceive the nature of science from the constructivists' ideas. In all the specific categories the percentages of science teachers who conceived the nature of science based on the traditionalists' view were greater than those who conceived the nature of science from the constructivists' approach.

Shown in table 6, the proportions of urban and rural science teachers who conceive science from the traditionalists' point of view were not significantly different. The table also shows that the proportions of urban and rural science teachers who conceived science from the constructivists' point of view were only significantly different in five items (items 2,6,10,12 and 17) out of twenty-two items. With this finding, $\mathrm{H}_{03}$ was therefore retained.

Table 7 shows that the science teachers' background did not seriously influence the science teacher's conceptions about the nature of science. However, a trend was identified among the different certificate holders moving from NCE (Nigeria Certificate in Education), through B. Sc Ed (Bachelor of Science in Education) to B. Sc (Bachelor of science). On the average proportion for all the categories; $61.60 \%, 59.37 \%$ and $57.78 \%$ of science teachers with NCE, B. Sc Ed, and B. Sc certificates respectively conceive the nature of science from the traditionalists' point of view. On the constructivists' idea about the nature of science, 31.43\%, 33.59\%, and 34.13\% of NCE, B. Sc Ed and B. Sc certificate holders respectively agreed with the options that are in line with the constructivists' idea. Still on the average proportion for all categories, the table indicates a gradual decrease in the percentages of science teachers who chose the traditionalists' options from the NCE, through B.Sc. Ed to B.Sc certificate holders. The table also showed that the percentage of science teachers who agreed with the constructivists' idea about the nature of science increased from B.Sc. Ed certificate holders (33.59\%) to B.sc certificate holders (34.33\%).

Table 8 shows that the proportions of NCE, B.Sc (Ed) and B. Sc certificate holders who agreed to the traditionalists' view of science were not significantly different except in item 17 where significant differences were found between NCE and B.Sc (Ed) and NCE, B.Sc. Also showed in table 8, the proportions of NCE, B. Sc (Ed) and B. Sc certificate holders who agreed with the constructivist's conceptions of the nature of science were significantly different only in four items $\left(4,9,17\right.$. \&20). With this finding, $\mathrm{H}_{\mathrm{O} 4}$ is therefore retained.

\section{Discussion}

This study is most significant in the sense that it has thrown more light on what our science teachers know and their conceptions about the nature of science (NOS). The findings of this study may pave way for the needs for curriculum innovations and reforms that will help improve science teaching and students understanding of what science is all about.

All the data collected on the science teachers conceptions, male and female science teachers conceptions, urban and rural science teachers conceptions and NCE , BSc.Ed and B.Sc certificate holders conceptions about the nature of science indicated that a greater proportion of the science teachers studied saw science from the traditionalists' point of view as shown in tables 1-8.

Of all the 22 items contained in the 5 categories, as shown in tables 1and2, the percentages of teachers who opted for the constructivist's idea about the nature of science were only highest in five items $(3,5,13,14$, and 22) while the science teachers conceptions based on the traditionalist's views had the highest percentages in the remaining 17 items. The notions where the highest percentages of science teachers agreed with the constructivist's view included; theories fit within certain paradigms, hence if these are old or untrue these are still helpful to scientists; scientific models do not describe reality as it is; scientific knowledge is tentative; scientific knowledge is formed though scientific and non scientific means; and scientific laws are only scientists best attempts to explain a part of nature. The findings of greater percentage of science teachers in all the variables of the study conceiving nature of science from the traditionalist's point of view and a lower percentage of science teachers of all descriptions conceiving science from the constructivist's idea contradicted the findings of Haidre (1999), but is consistent with the findings of Thyne and Kwen (2005), Kucuk (2008), Shah (2009) and Iqbal (2009).

Haider (1999) found and concludes that science teachers in Emirates hold mixed views, equal number of teachers holding traditional and contemporary (constructivist) views. Haider (1999) attributed the existence of traditional views to historical factor and the constructivist views to religious background. The studies by Thyne and Kwen 
(2003), Kucuk (2008), Shah (2009) and Iqbal (2009) indicated that a greater percentage of science teachers in their various areas of study conceived the nature of science from the traditionalist point of view. Specifically, Iqbal et al (2009) studied secondary school science teachers' views about the nature of science. On the analysis of data collected, they found that the views of majority of school science teachers like what is found in this study fell in the traditional domain. This kind of finding as shown in this study may be explained with five factors which could influence teachers conceptions about the nature of science.

The first among them is the way science is taught in schools which does not allow for the development of the right notion about the nature of science. Just like the situation in Nigeria, Iqbal et al (2009) noted that during science teaching in schools in Pakistan, strong emphasis is placed on content knowledge and teachers promote the view of science that they themselves were oriented. Ajaja and Eravwoke (2010) found that the dominant method for teaching science in Nigeria is the traditional teaching method which is teacher centered rather than allowing student to create knowledge for themselves.

The second reason which may have influenced this kind of result is lack of laboratories /ill -equipped laboratories for teaching and learning science. In most schools in Nigeria, the existence of well equipped laboratories that will encourage the use of guided inquiry for teaching and learning science is hard to come by. The best science teachers do is the verification of concepts, theories and laws which hinge on the traditionalist's notion about the nature of science. Ajaja (2009b) in a study on teaching of science in Nigerian schools found that practical science lessons are only organized during the preparation for the final school certificate examinations.

The science teacher's previous experience during their trainings is the third factor which may have also influenced their notion about the nature of science. This suggestion tends to agree with the finding of Shah (2009) that the teacher's belief about the nature of science were embedded in his own experiences of learning and learning to teach and indicates that in some cases. Most of the teachers' conceptions about the nature of science may have been due to the long-held conceptions inherited from their former teachers and the learning experiences they had during their earlier lives.

The forth factor which may have influenced science teachers conceptions of the nature of science from the traditionalists' point of view is the method employed in the evaluation of science learning outcomes. Most of the skills evaluated are on lower level cognitive domain. Examinations and assignments which demand the use of inquiry approach to solve problems are hardly given. For example private candidate examinations conducted by the West African Examination Council (WAEC) and National Examination Council (NECO) examine candidates in practical science by the use of "Test of Practical knowledge" which is entirely theoretical . Science teachers who are used to this method cannot view the nature of science from the constructivists' point of view because their teachings have never been inquiry based.

The types of books science teachers use for teaching is the fifth factor that may have also influenced their conceptions about the nature of science. Almost all the science textbooks used for science teaching and learning were written on the format of knowledge transmission. Books written on an investigative format are hardly available. Teachers who use such books for teaching will hardly understand that science could be effectively learned and taught using an investigative approach. The idea that the kinds of textbooks used by teachers for instruction could influence their conception about the nature of science can be buttressed with the stand of Gallangher (1991) that secondary school science teachers respond to textbooks in a way that contribute to transmission mode of science teaching.

The findings of non-significant influences of sex, school location and kinds of certificates possessed by science teachers on science teachers conceptions about the nature of science was no surprise. A majority of all these categories of teachers perceived science mainly from the traditionalist's point of view. The reasons are very clear. All these categories of teachers were trained with the same curricula. Also most of the teacher educators were trained through the same process. The training which they offer to science teachers', centre on transmission of knowledge without any serious attempt to emphasis constructivist ideas in science teaching and learning. The implication of this is that for any change to be effected there must be a deliberate attempt to innovate all the curricula used for science teachers training programmes to include the tenets of constructivism in them.

This study also found that the percentage of science teachers who opted for constructivist's ideas on the nature of science tended to have increased among BSc.(Ed) and B.Sc graduates when the NCE certificate holders were compared with the holders of B.Sc (Ed) on one side and NCE with B.Sc holders on another side. This development may not be unconnected with the varying amount of science concepts and methods of doing science these categories of science teachers were exposed to during the teacher preparatory programmes. The NCE certificate holders will have to spend another three years in the university before they are awarded either B.Sc (Ed) 
or B.Sc in any of the science subjects. B.Sc(Ed) certificate holders take less science courses than the B.Sc graduates because they take courses on teaching methods. These varying amounts of courses taken by the various categories of science teachers may be responsible for the varying percentages of them who conceived the nature of science from the constructivists' points of view.

\section{Conclusion}

The findings of this study indicates that greater percentage of science teachers in third world countries (like Nigeria) still conceive the nature of science from the traditionalist's point of view. This conception of nature of science from the traditionalist's point of view by science teachers in Edo and Delta states of Nigeria may have been influenced by five factors which include: way science is taught in schools, lack of equipped laboratories for inquiry teaching and learning, teachers previous experiences during their training, method of evaluation of learning outcomes, and types of textbooks used for instruction.

This development, therefore calls for putting in place well-planned science teacher education programmes that will help teachers transform their beliefs in a significant way. There are however, assumptions that teachers conceptions/beliefs are resistant to change. This therefore calls for external assistance in the form of seminars, conferences, on the job re-training, and science talk-shops to challenge existing beliefs and provide alternative approaches to practice. Similarly, it is necessary to implement the new learning in the real classroom situation.

\section{References}

Abd-El-Khalick, F, Bell, R.L, \& Laderman, N.C (1998). The nature of science instructional practice: Making the unnatural natural. Science Education, 82, 417-437

Abd-El-Khalick, F., \& Laderman, N.C (2000a). Improving science teachers' conceptions of the nature of science: A critical review of literature .International Journal of Science Education, 22, 665-701

Ajaja, O. P (2009a). Teaching methods across disciplines Ibadan: Brown Prints

Ajaja,O. P. (2009b). evaluation of science teaching in secondary schools in Delta State 2- Teaching the science . International Journal of Educational Sciences, 1(2); 119-129

Ajaja, O. P., \& Eravwoke O.U (2010). Effects of cooperative learning strategy on jounior secondary school students achievement in integrated science. Electronic Journal of Science Education, 14(1); 1-18

Akerson, V. L., \& Volrich, M. (2006). Teaching nature of science explicitly in a first grade internship setting .Journal of Research in Science Teaching, 43, 377-374

American Association for the Advancement of Science (1990). Science for all Americans New York: University Press

Bell, R. L. (2003). Teaching the nature of science through process skills: Activities for grades 3-8. New York:Allyn \&Bacon/Longman

Borich, G.D. (2004). Effective teaching methods, fifth edition. New Jersey: Pearson Merrill Prentice Hall

Corbern, W.W., \& Loving, C. C (2002). An investigation of pre-service elementary teacher's thinking about science. Journal of Research in Science Teaching, 39(10), 1016-1031.

Gallagher, J. (1991). Prospertive and practicing secondary school science teacher's knowledge and beliefs about the philosophy of science. Science Education, 75, 121.

Haidar, A. H. (1999). Emirates pre-service and in-service teachers' views about the nature of science. International Journal of Science Education, 21(8); 807-822

Halai, N \& Mc Nicholl, J (2004). Teachers' conceptions of the nature of science: A comparative study from Pakistan and England .School Science Review, 86(314); 93-89

Iqbal, H. M, Azam, S., \& Rana, R.A. (2009). Secondary school science teachers views about the nature of science. Bulletin of Education and Research, 31(2); 29-44

Johnson , B., \& Christensen, L.(2000). Educational research. Boston: Allyn and Bacon.

Kang, S, Scharmanna, L.C Ve. Noll, T. (2005). Examining students' views on the nature of science: Results from Korean $6^{\text {th }}, 8^{\text {th }} \& 10^{\text {th }}$ graders . Science Education, 89(2005); 315- 334

Kucuk, M. (2008). Improving pre-service elementary teachers' views of the nature of science using esplict-reflective teaching in a science, technology and society course. Australian Journal of Teacher Eduucation, 33(2), 16-40

Lederman, N.G (1998). The state of science education: Subject matter without context. Electronic Journal of 
Science Education (on-line serial) 3(2). [Online] Available: http./unr.edu/homepage/cannon/ejse. (January 5, 2010)

Lederman, N. G, Abd-El-Khalick, F, Bell, R.L, \& Schwwartz, R.S (2002). Views of nature of science questionnaire (VNOS): Towards valid and meaningful assessment of learners' conceptions of nature of science. Journal of Research in Science Teaching, 39, 497-521

Lederman, N. G (2006). Research on nature of science: Reflections on the past, anticipations of the future .AsiaPacific Forum on Science Learning and Teaching, 7(1); 2.

Lin, H., \& Chen, C. (2002). Promoting pre-service chemistry teachers' understanding about the nature of science through history. Journal of Research in Science Teaching, 39(9), 773-792.

Lin, H, Chiu, L., \& Chan, C. (2002). Student understanding of nature of science and their problem solving skills. International Journal of Science Education, 26(1), 101-112

National Research Council (1996). National science education standard. Washington, DC: National Academics Press.

Richardson, V. (1997). Constructivist teaching and teacher education: theory and practive. In V Richardson (Ed), constructivist teacher education : Building new understanding. Washington, D.C: Falmer press.

Shah, M.Z. (2009). Exploring the conceptions of a science teacher from Karachi: About the nature of science. Eurasia Journal of Mathematics, Science and Technology Education, 5(3); 305-315

Thorndike, R.L \& Hagen, E.P. (1997). Measurement and evaluation. New York: John Wiley and Sons

Thye, T.L \& Kwen, B. H (2003). Assessing the nature of science views of Singaporean pre-service teachers. A paper presented at the annual conference of the New Zealand/ Australian Association for Research in Education, Auckland. Paper Number: Tan 03096

WAEC (2006). Chief examiners report: Lagos: WEAC press Ltd

WAEC (2007). Chief examiners report: Lagos: WEAC press Ltd

WAEC (2008). Chief examiners report: Lagos: WEAC press Ltd

WAEC (2009). Chief examiners report: Lagos: WEAC press Ltd

WAEC (2010). Chief examiners report: Lagos: WEAC press Ltd

Wisman, D.C (1999). Research strategies for education New York: Wadsworth Publishing Company 


\section{Appendix I}

Teachers conceptions of nature science questionnaire (TCNQ)

The research work which calls for this questionnaire is purely academic in purpose and it is aimed at finding out the conception of science teachers about the nature of science (NOS) for the purpose of improving science teaching and learning in Nigeria.

Instructions to science Teachers

(a) Fill in the spaces provided by writing

(b) Select only one option of your choice in each of the items under each category and tick any of the boxes based on your conception of NOS

(c) Respond to all the statements without consulting anyone , and hand it immediately to the research assistant. Thanks for your co-operation

\section{Section A}

Personal Data

1. Name of school

2. Location of school

3. Sex of science Teacher-

4. Science subject taught

5. Certificate possessed by science teacher

\section{Section B}

\section{Categories}

\section{Scientific Theories}

(1a) Theories are based directly on observation, where observation to exactly what you see .Yes [ ] Don't know [ ]

(1b) Observation is influenced by theories scientists hold. Because experimental procedures differ according to theories, hence observation differs. Yes [ ] Don't know [ ]

(2a) Scientists discover theories, because theories are there in nature and scientist just have to find them. Yes [ ] Don't know [ ]

(2b) Scientist invents theories, because theory invention comes from the mind. Yes [ ] Don’t know [ ]

(3a) Old theories are those, which had been proven untrue, are of no use to scientist. Yes [ ] Don’t know [ ]

(3b) Theories fit within certain paradigms, hence if these are old or untrue these are still helpful to scientist. Yes [ ] Don't know [ ]

(4a) A theory is a hypothesis that has been proven to be correct, because hypothesis must be subjected to empirical test and if proven true it becomes a theory. Yes [ ] Don't know [ ]

(4b) A theory is validated by its connections to other theories generally accepted within the scientific community. Yes [ ] Don’t know [ ]

(5a) Scientific models (eg. The model of an atom) are copies of reality, since they describe reality as it is. Yes [ ] Don't know [ ]

(5b) Scientific models do not describe reality as it is. These are scientist ideas or educated guesses, because scientists cannot see real things. Yes [ ] Don’t know [ ]

\section{Role of scientists}

(6a) A scientist evaluates scientific claims exclusively through empirical evidence; Yes [ ] Don't know [ ]

(6b) A scientist dose not exclusively needs to use empirical evidence; he may use imagination or creativity

(7a) A scientist is someone who is objective and open minded in all his act. Yes [ ] Don't know [ ]

(7b) A scientist is influenced by many factors, eg previous knowledge, logic and social factors. Yes [ ] Don't know [ ]

(8a) The best scientists are those who follow the steps of the scientific method. Yes [ ] Don't know [ ]

(8b) The best scientist are those who use method that might obtain favourable results. Yes [ ] Don’t know [ ]

(9a) A scientist strives to discover absolute truth Yes [ ] Don’t know [ ] 
(9b) A scientist works within the scientific community to find the best way to explain the part of nature. Yes [ ] Don't know [ ]

(10a) Scientist report data exactly as their senses perceive them. Yes [ ] Don't know [ ]

(10b) Recording data is influenced by other factors, eg previous knowledge Yes [ ] Don’t know [ ]

\section{Scientific knowledge}

(11a) Scientific knowledge corresponds directly to reality. Yes [ ] Don’t know [ ]

(11b) Scientific knowledge is our understanding of reality , and reality as it is. Yes [ ] Don't know [ ]

(12a) Scientific knowledge is cumulative. It increases with observation. Yes [ ] Don't know [ ]

(12b) Scientific knowledge is not cumulative. It also goes through jumps. Yes [ ] Don’t know [ ]

(13a) Scientific knowledge is final not tentative. Yes [ ] Don’t know [ ]

(13b) Scientific knowledge is tentative. Yes [ ] Don't know [ ]

(14a) Scientific knowledge is formed only through scientific means. Yes [ ] Don’t know [ ]

(14b) Scientific knowledge is formed through scientific and non scientific means. Yes [ ] Don't know [ ]

(15a) Scientific knowledge is generated first only through observations. Yes [ ] Don't know [ ]

(15b) Scientific knowledge might also be generated through imagination or creativity. Yes [ ] Don’t know [ ]

(16a) There is a single method to perform science that is the scientific method. Yes [ ] Don’t know [ ]

(16b) There is no single method to perform science. There are methods, eg creativity, imagination and originality. Yes [ ] Don't know [ ]

(17a) The scientific method is a step by step process. Yes [ ] Don't know [ ]

(17b) The scientist do not necessarily have to follow the sequence of the scientific method. Yes [ ] Don't know [ ]

(18a) The scientific method must be planned out in advance of inquiry. Yes [ ] Don’t know [ ]

(18b) Scientist can adjust their method of inquiry in the middle of an investigation and still get valid result. Yes [ ] Don't know [ ]

(19a) The use of scientific method is necessary to discover and validate theories. Yes [ ] Don't know [ ]

(19b) Scientists use several methods according to circumstances. The scientific method is only one of those methods Yes [ ] Don’t know [ ]

\section{Scientific laws}

(20a) Scientists discover scientific laws, because these laws are there in nature and scientists just have to find them. Yes [ ] Don't know [ ]

(20b) Scientists do not invent what nature does but they invent the laws, which describe what nature does.

Yes [ ] Don't know [ ]

(21a) Scientist interpret the laws found in nature. Yes [ ] Don’t know [ ]

(21b) Scientist Invent scientific laws. Yes [ ] Don’t know [ ]

(22a) Scientific laws can be proven to be absolutely true. Yes [ ] Don’t know [ ]

(22b) Scientific laws are only scientists' best attempts to explain a part of nature. Yes [ ] Don’t know [ ] 
Table 1. Conceptions of science teacher about nature of Science expressed in percentage $\mathrm{N}=400$

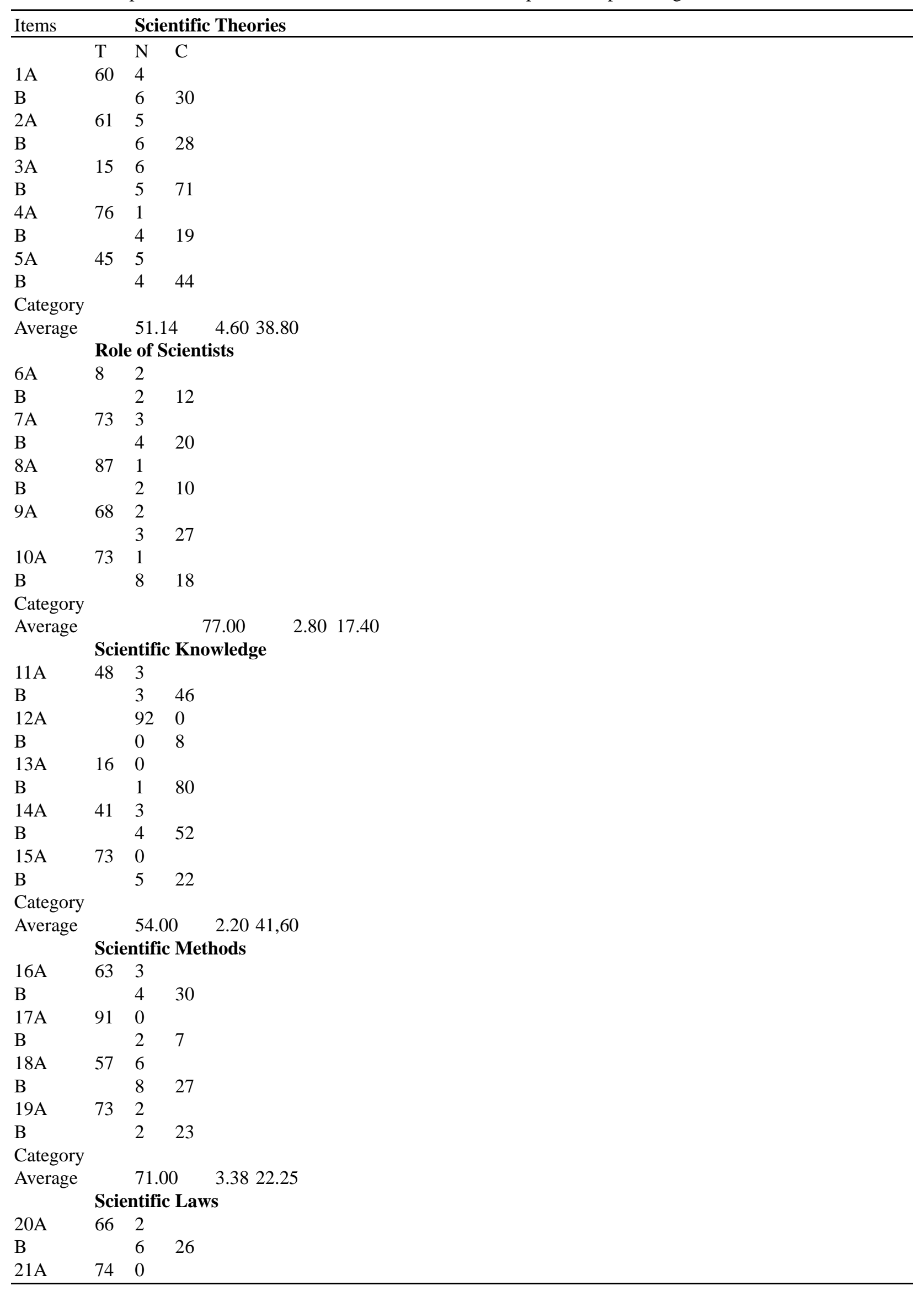




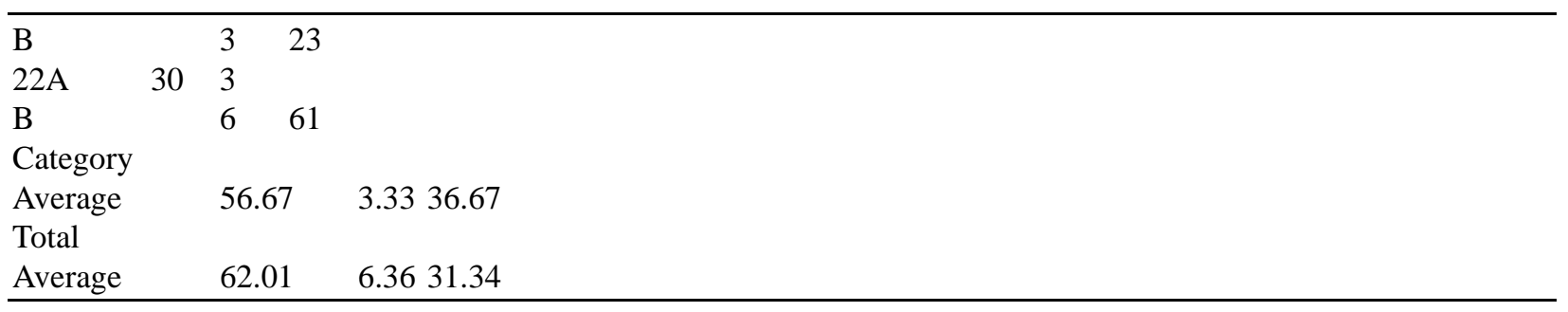

Table 2. Percentage of science Teachers responding “Agree” to questions about the traditionalists' and constructivists' conception of science

\begin{tabular}{|c|c|c|}
\hline \multirow[t]{2}{*}{ Item Nos } & \multicolumn{2}{|c|}{ Percentage responding to “Agree” } \\
\hline & Traditionalists' view & Constructivists' view \\
\hline & $\mathrm{N}=400$ & \\
\hline $1 \mathrm{a} \& \mathrm{~b}$ & 60 & $30 * *$ \\
\hline 2 a $\& b$ & 61 & $28 * *$ \\
\hline 3 a $\& b$ & 15 & $71^{* *}$ \\
\hline 4 a $\& b$ & 76 & $19 * *$ \\
\hline 5 a $\& b$ & 45 & 46 \\
\hline 6 a $\& b$ & 84 & $12 * *$ \\
\hline 7 a $\& b$ & 73 & $20 * *$ \\
\hline 8 a $\& b$ & 87 & $10^{* *}$ \\
\hline 9 a $\& b$ & 68 & $27 * *$ \\
\hline 10 a $\& b$ & 73 & $18^{* *}$ \\
\hline 11 a \&b & 48 & 46 \\
\hline 12 a $\& b$ & 92 & $8 * *$ \\
\hline 13 a $\& b$ & 16 & $80^{* *}$ \\
\hline 14 a $\& b$ & 41 & $52 * *$ \\
\hline 15 a $\& b$ & 73 & $22^{* *}$ \\
\hline 16 a \&b & 63 & $30 * *$ \\
\hline 17 a $\& b$ & 91 & $7 * *$ \\
\hline 18 a $\& b$ & 57 & $29 * *$ \\
\hline 19 a \&b & 73 & $23^{* *}$ \\
\hline 20 a $\& b$ & 66 & $26 * *$ \\
\hline 21 a \&b & 74 & $23 * *$ \\
\hline 22 a $\& b$ & 30 & $61^{* *}$ \\
\hline
\end{tabular}

$* * \mathrm{X}^{2}=$ test of differences between traditionalists' and constructivists' views of science, significant at $\mathrm{p}<0.05$. 
Table 3. Conceptions of male and female science teachers about nature of science expressed in percentage Male $\mathrm{N}=240$, Female $\mathrm{N}=160$

$$
\text { MALE }
$$

FEMALE

\begin{tabular}{lllllll}
\hline \multicolumn{7}{c}{ Scientific Theories } \\
\hline Item & T & N & C & T & N & C \\
1A & 58 & 3 & & 62 & 2 & \\
B & & 5 & 54 & & 3 & 31 \\
2A & 63 & 3 & & 60 & 1 & \\
B & & 4 & 30 & & 6 & 35 \\
3A & 20 & 5 & & 17 & 6 & \\
B & & 2 & 73 & & 3 & 74 \\
4A & 79 & 1 & & 76 & 2 & \\
B & 2 & 18 & & 5 & 17 & \\
5A & 41 & 5 & & 47 & &
\end{tabular}

B 4

Category 52.20

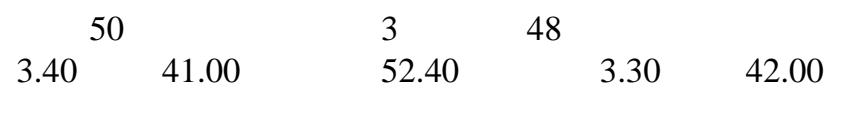

\section{Average}

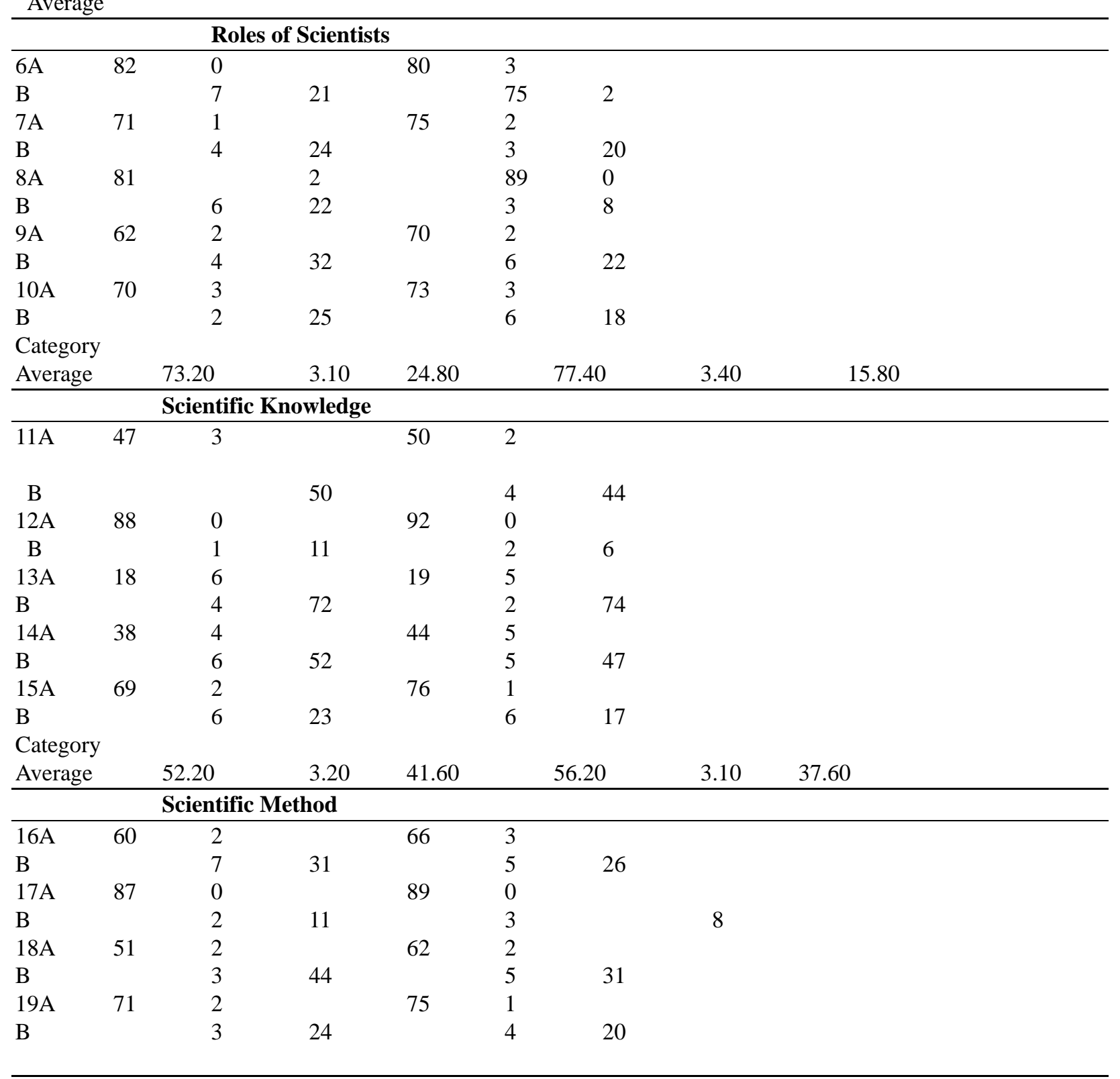




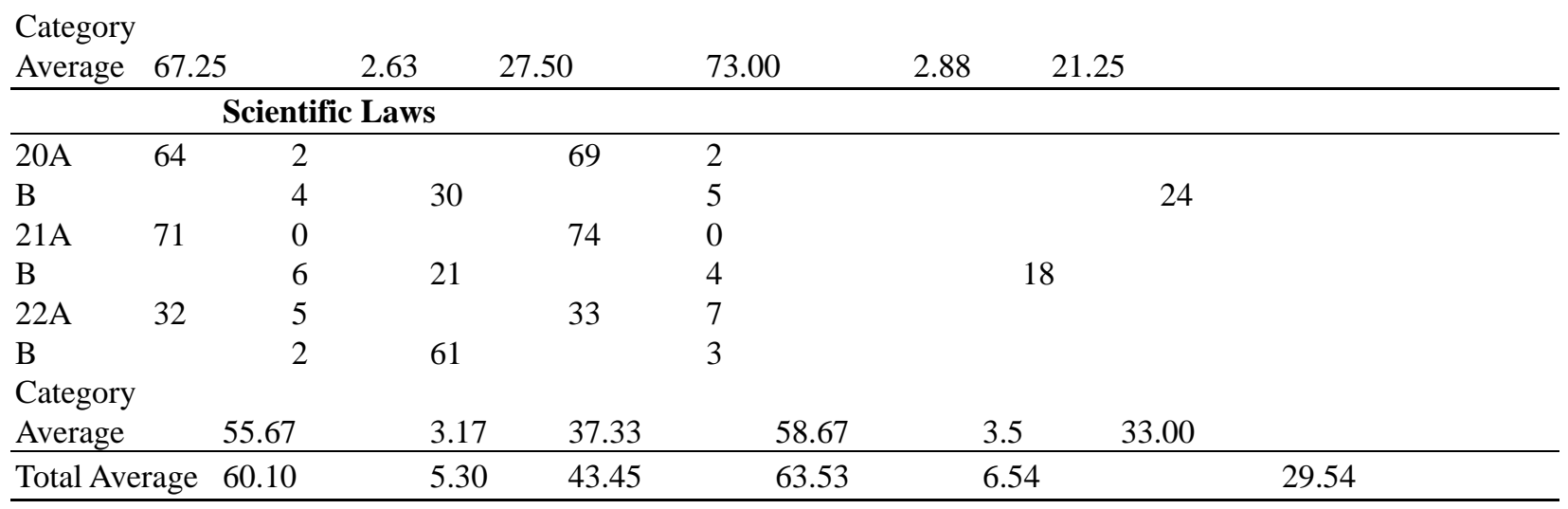

Table 4. Percentage of male and female science teachers responding to "Agree" to questions about the traditionalists' and constructivists" conceptions of nature of science

\begin{tabular}{|c|c|c|c|c|}
\hline \multirow[t]{3}{*}{ Item Nos } & \multicolumn{4}{|c|}{ percentage responding “Agree" } \\
\hline & \multicolumn{2}{|c|}{ Traditionalists' view } & \multicolumn{2}{|c|}{ constructivists' view } \\
\hline & Male $=\mathbf{2 4 0}$ & Female $=160$ & Male $=\mathbf{2 4 0}$ & Female $=160$ \\
\hline $1 \mathrm{a} \& \mathrm{~b}$ & 58 & 62 & 34 & 31 \\
\hline $2 \mathrm{a} \& \mathrm{~b}$ & 63 & 60 & 30 & 35 \\
\hline 3 a $\& b$ & 20 & 17 & 73 & 74 \\
\hline 4 a $\& b$ & 79 & 76 & 18 & 17 \\
\hline 5 a \&b & 41 & 47 & 50 & 48 \\
\hline 6 a $\& b$ & 82 & 80 & 21 & 12 \\
\hline 7 a \&b & 71 & 75 & 24 & 20 \\
\hline 8 a \&b & 81 & 89 & 22 & 8 \\
\hline 9 a $\& b$ & 62 & 70 & 32 & 22 \\
\hline 10 a $\& b$ & 70 & 73 & 25 & 18 \\
\hline $11 \mathrm{a} \& \mathrm{~b}$ & 47 & 50 & 50 & 44 \\
\hline 12 a $\& b$ & 88 & 92 & 11 & 6 \\
\hline 13 a $\& b$ & 18 & 19 & 72 & 72 \\
\hline $14 \mathrm{a} \& \mathrm{~b}$ & 38 & 44 & 52 & 47 \\
\hline 15 a $\& b$ & 69 & 76 & 23 & 17 \\
\hline 16 a $\& b$ & 60 & 66 & 31 & 26 \\
\hline 17 a $\& b$ & 87 & 89 & 11 & 8 \\
\hline 18 a $\& b$ & 51 & 62 & 44 & 31 \\
\hline 19 a $\& b$ & 71 & 75 & 24 & 20 \\
\hline 20 a $\& b$ & 64 & 69 & 30 & 24 \\
\hline 21 a $\& b$ & 71 & 74 & 21 & 18 \\
\hline 22 a \&b & 32 & 33 & 61 & 57 \\
\hline
\end{tabular}

$\mathrm{X}^{2}=$ test of differences between males and females science teachers on conceptions of science from the traditionalists' and constructivists' of views of science, significant at $\mathrm{p}<0.05$. 
Table 5. Conceptions of urban and rural science teachers about the nature of science expressed in percentage

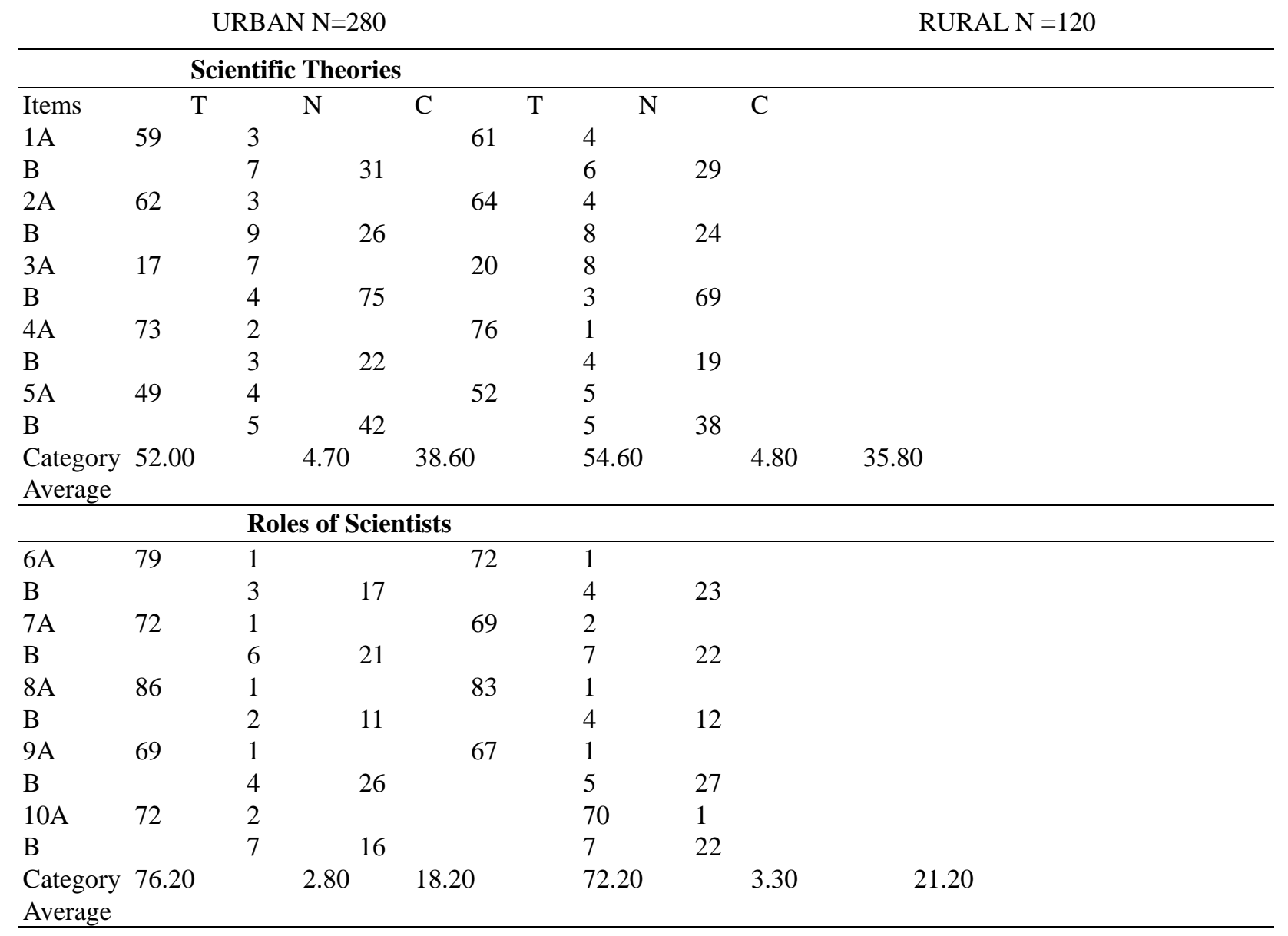

\begin{tabular}{|c|c|c|c|c|c|c|c|c|}
\hline \multicolumn{9}{|c|}{ Scientific Knowledge } \\
\hline $11 \mathrm{~A}$ & 50 & 2 & & 51 & 2 & & & \\
\hline B & & 4 & 44 & & 3 & 44 & & \\
\hline $12 \mathrm{~A}$ & 89 & 0 & & 80 & 0 & & & \\
\hline B & & 0 & 11 & & 3 & 11 & & \\
\hline $13 \mathrm{~A}$ & 18 & 3 & & 19 & 6 & & & \\
\hline B & & 1 & 78 & & 2 & 73 & & \\
\hline $14 \mathrm{~A}$ & 44 & 3 & & 47 & 3 & & & \\
\hline B & & 4 & 49 & & 3 & 47 & & \\
\hline $15 \mathrm{~A}$ & 70 & 0 & & 71 & 0 & & & \\
\hline B & & 4 & 26 & & 6 & 23 & & \\
\hline $\begin{array}{l}\text { Category } \\
\text { Average }\end{array}$ & 54.20 & & 2.10 & 41.60 & 53.80 & & 2.80 & 40.80 \\
\hline \multicolumn{9}{|c|}{ Scientific Method } \\
\hline$\overline{16 \mathrm{~A}}$ & 61 & 3 & & 63 & 2 & & & \\
\hline B & & 4 & 35 & & 4 & 31 & & \\
\hline $17 \mathrm{~A}$ & 89 & 0 & & 85 & 0 & & & \\
\hline B & & 3 & 8 & 56 & 5 & & & \\
\hline $18 \mathrm{~A}$ & 54 & 8 & & 7 & 32 & & & \\
\hline B & & 6 & 32 & & 71 & 2 & & \\
\hline $19 \mathrm{~A}$ & 69 & 2 & & & 3 & 24 & & \\
\hline B & & 2 & 27 & & 3 & 24 & & \\
\hline $\begin{array}{l}\text { Category } \\
\text { Average }\end{array}$ & 68.25 & & 3.50 & 24.75 & 68.75 & & 3.52 & 27.25 \\
\hline
\end{tabular}




$\begin{array}{lllllll}20 \mathrm{~A} & 63 & 3 & & 65 & 3 & \\ \mathrm{~B} & & 5 & 28 & & 5 & 27 \\ & & & & & & \\ 21 \mathrm{~A} & 76 & 0 & & 78 & 0 & \\ \text { B } & & 3 & 21 & & 4 & 18 \\ 23 \mathrm{~A} & 35 & 4 & & 37 & 5 & \\ \text { B } & & 5 & 56 & & 4 & 34\end{array}$

Category

Average $\quad 58.00$

Total Average 61.73

$3.33 \quad 35.33$

31.70

60.00

$3.50 \quad 33$

Table 6. Percentage of Urban and rural science teachers responding "Agree” to questions about the traditionalists' and constructivist's conceptions of nature of science.

\begin{tabular}{|c|c|c|c|c|}
\hline \multirow[t]{4}{*}{ Item Nos } & \multicolumn{4}{|c|}{ Percentage responding "Agree" } \\
\hline & \multicolumn{4}{|c|}{ Traditionalists' view constructivists' view } \\
\hline & Urban & Rural & Urban & Rural \\
\hline & $\mathrm{N}=280$ & $\mathrm{~N}=120$ & $\mathrm{~N}=280$ & $\mathrm{~N}=120$ \\
\hline $1 \mathrm{a} \& \mathrm{~b}$ & 59 & 61 & 31 & 29 \\
\hline $2 \mathrm{a} \& \mathrm{~b}$ & 62 & 64 & 36 & $24 * *$ \\
\hline 3 a $\& b$ & 17 & 20 & 72 & 69 \\
\hline $4 \mathrm{a} \& \mathrm{~b}$ & 73 & 76 & 22 & 19 \\
\hline $5 \mathrm{a} \& \mathrm{~b}$ & 49 & 52 & 43 & 38 \\
\hline $6 \mathrm{a} \& \mathrm{~b}$ & 79 & 72 & 17 & $23^{* *}$ \\
\hline $7 \mathrm{a} \& \mathrm{~b}$ & 72 & 69 & 21 & 22 \\
\hline 8 a $\& b$ & 86 & 83 & 11 & 12 \\
\hline 9 a $\& b$ & 69 & 67 & 26 & 27 \\
\hline $10 \mathrm{a} \& \mathrm{~b}$ & 75 & 70 & 16 & $22 * *$ \\
\hline $11 \mathrm{a} \& \mathrm{~b}$ & 50 & 51 & 44 & 44 \\
\hline $12 \mathrm{a} \& \mathrm{~b}$ & 89 & 80 & 11 & $17^{* *}$ \\
\hline 13 a $\& b$ & 18 & 19 & 78 & 73 \\
\hline 14 a \&b & 44 & 47 & 49 & 47 \\
\hline 15 a \&b & 70 & 71 & 26 & 23 \\
\hline 16 a \&b & 61 & 63 & 32 & 31 \\
\hline 17 a \&b & 89 & 85 & 8 & $22 * *$ \\
\hline $18 \mathrm{a} \& \mathrm{~b}$ & 54 & 56 & 32 & 32 \\
\hline 19 a $\& b$ & 69 & 71 & 27 & 29 \\
\hline 20 a $\& b$ & 63 & 65 & 29 & 27 \\
\hline $21 \mathrm{a} \& \mathrm{~b}$ & 76 & 78 & 31 & 18 \\
\hline 22 a $\& b$ & 35 & 37 & 56 & 54 \\
\hline
\end{tabular}

** $\mathrm{X}^{2}=$ test difference between urban and rural science teachers on conceptions of science from the traditionalists' and constructivists' views of nature of science, significant at $\mathrm{p}<0.05$.

Table 7. Conceptions of NCE, BSc.Ed and BSc science teachers about nature of science expressed in percentage N.C.E $\quad \mathrm{N}=200$.

BSc Ed N=102. BSc $\mathrm{N}=98$

\begin{tabular}{lllllllllll}
\hline \multicolumn{10}{c}{ Scientific Theories } & \\
\hline Items & \multicolumn{1}{ll}{ T } & N & C & T & N & C & T & N & C \\
1A & 60 & 4 & & 57 & 5 & & 58 & 4 & & \\
B & & 6 & 30 & & 5 & 33 & & 6 & 32 & \\
2A & 62 & 3 & & 60 & 4 & & 61 & 5 & & \\
B & & 9 & 26 & & 8 & 28 & & 8 & 26 & \\
3A & 15 & 6 & & 16 & 9 & & 15 & 6 & & \\
B & & 5 & 71 & & 5 & 70 & & 3 & 76 & \\
4A & 73 & 22 & & 70 & 2 & & 68 & 1 & & \\
B & & 3 & 22 & & 3 & 35 & & 4 & 27 & \\
\hline
\end{tabular}




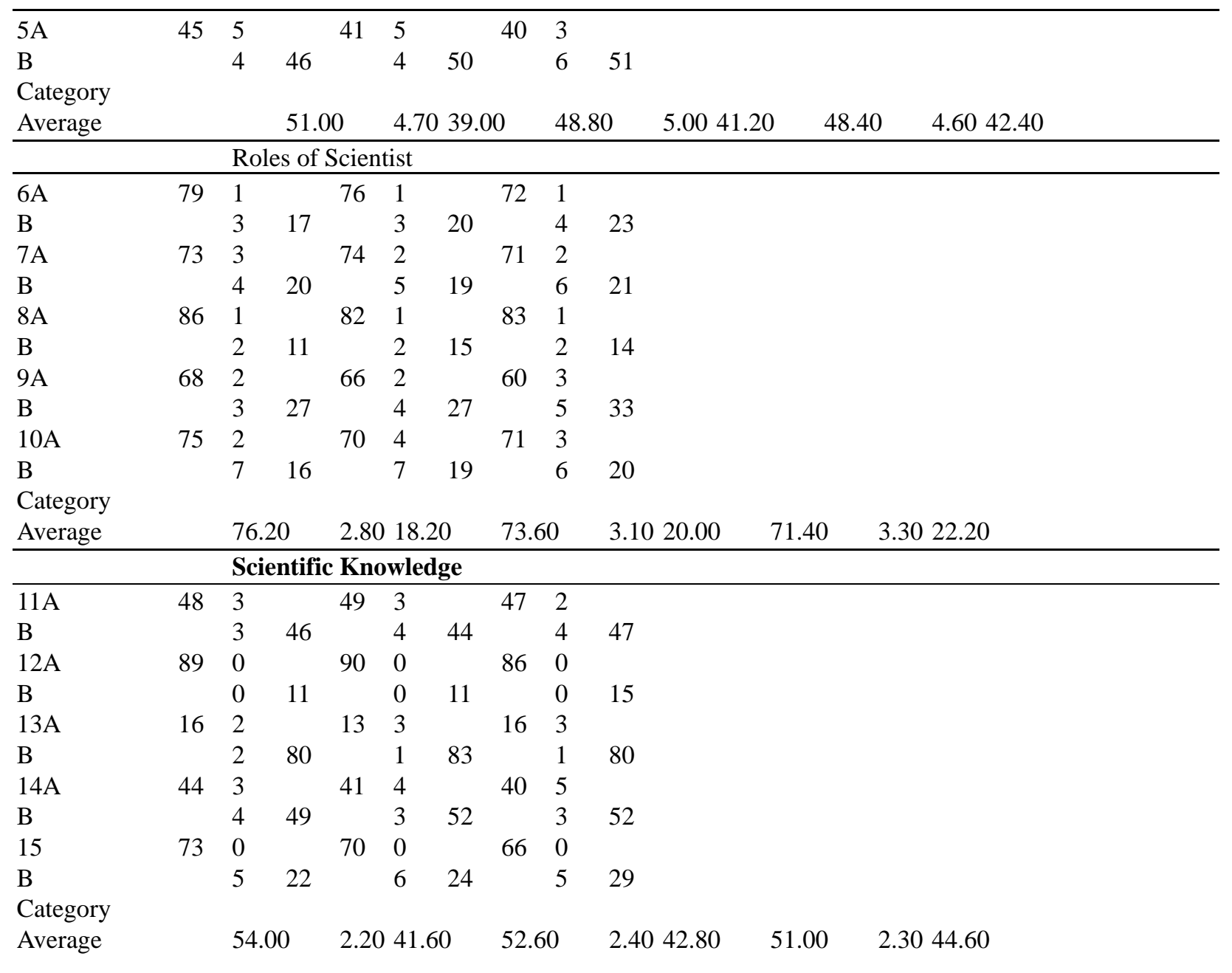

\section{Scientific Methods}

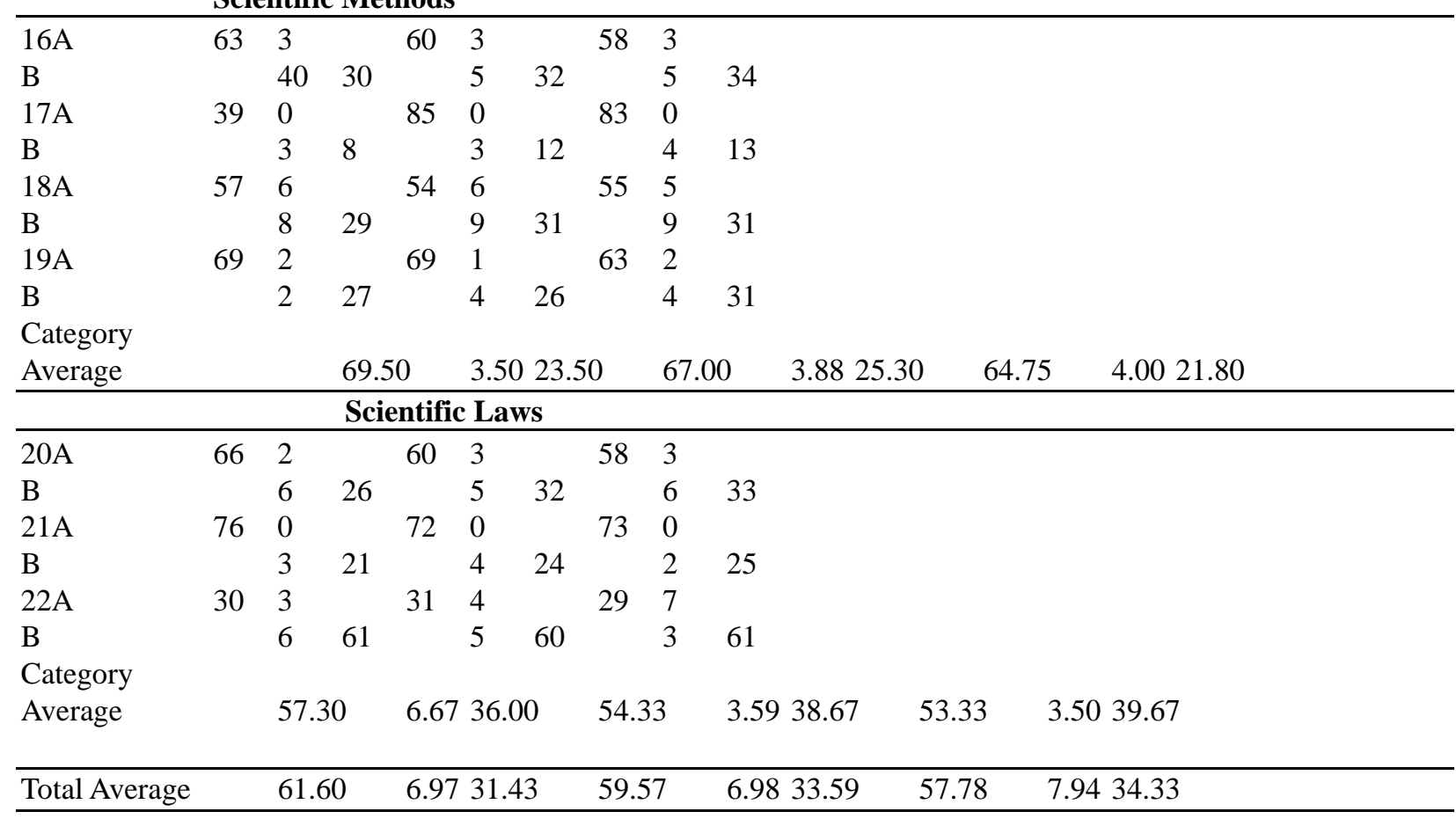


Table 8. Percentage of NCE, B.Sc (Ed), B.Sc certificate holders respond “Agree” to questions about the traditionalists' and constructivists' conceptions of science.

\begin{tabular}{|c|c|c|c|c|c|c|c|}
\hline \multirow{4}{*}{ Items Nos. } & \multirow[t]{4}{*}{ Percentage } & \multicolumn{3}{|c|}{ responding } & \multicolumn{3}{|c|}{ “Agree” } \\
\hline & & \multicolumn{6}{|c|}{ Percentage responding “Agree” } \\
\hline & & \multirow{2}{*}{\multicolumn{3}{|c|}{ Traditionalists' view }} & \multicolumn{3}{|c|}{ constructivists’ view } \\
\hline & & & & & NCE & $\mathrm{BSc}(\mathrm{Ed})$ & $\mathrm{BSc}$ \\
\hline Item Nos & & \multicolumn{3}{|c|}{$N=200 N=102 \mathrm{~N}=98$} & $\mathrm{~N}=200$ & $\mathrm{~N}=102$ & $\mathrm{~N}=98$ \\
\hline $1 \mathrm{a} \& \mathrm{~b}$ & & 60 & 57 & 58 & 30 & 33 & 32 \\
\hline $2 \mathrm{a} \& \mathrm{~b}$ & & 62 & 60 & 61 & 26 & 28 & 26 \\
\hline 3 a $\& b$ & & 15 & 16 & 15 & 71 & 70 & 76 \\
\hline 4 a $\& b$ & & 73 & 70 & 68 & 22 & 35 & $27 * *$ \\
\hline 5 a $\& b$ & & 45 & 41 & 40 & 46 & 50 & 51 \\
\hline 6 a \&b & & 79 & 76 & 72 & 17 & 20 & 23 \\
\hline 7 a \&b & & 73 & 74 & 71 & 17 & 20 & 23 \\
\hline 8 a $\& b$ & & 86 & 82 & 83 & 83 & 11 & 14 \\
\hline 9 a $\& b$ & & 68 & 66 & 60 & 27 & 27 & $33^{* *}$ \\
\hline 10 a $\& b$ & & 75 & 70 & 71 & 16 & 19 & 20 \\
\hline $11 \mathrm{a} \& \mathrm{~b}$ & & 48 & 49 & 47 & 46 & 44 & 47 \\
\hline 12 a $\& b$ & & 89 & 90 & 86 & 11 & 11 & 15 \\
\hline 13 a $\& b$ & & 16 & 13 & 16 & 80 & 83 & 80 \\
\hline $14 \mathrm{a} \& \mathrm{~b}$ & & 44 & 41 & 40 & 49 & 52 & 52 \\
\hline 15 a $\& b$ & & 73 & 70 & 66 & 22 & 24 & 29 \\
\hline 16 a $\& b$ & & 63 & 60 & 58 & 30 & 32 & 34 \\
\hline 17 a $\& b$ & & 39 & 85 & $83^{* *}$ & 58 & 12 & $13^{* *}$ \\
\hline 18 a $\& b$ & & 57 & 54 & 55 & 29 & 31 & 37 \\
\hline 19 a $\& b$ & & 69 & 69 & 63 & 27 & 26 & 31 \\
\hline 20 a $\& b$ & & 66 & 60 & 58 & 26 & 32 & $33^{* *}$ \\
\hline 21 a $\& b$ & & 76 & 72 & 73 & 21 & 24 & 25 \\
\hline 22 a $\& b$ & & 30 & 31 & 29 & 61 & 60 & 61 \\
\hline
\end{tabular}

${ }^{* *} \mathrm{X}^{2=}$ test of differences among NCE, BSc (Ed) and BSc certificate holders responding "Agree” to questions about the traditionalists' and constructivists' views of science, significant at $\mathrm{p}<0.05$ 